\title{
Organizational culture and quality under the management perception of the hotel sector
}

\section{Cultura organizacional y la calidad bajo la percepción gerencial del sector hotelero}

QUIJANO-GARCÍA, Román Alberto $\dagger^{*}$, BERTTOLINI-DIAZ, Gilda María and ARGUELLES-MA, Luis Alfredo

Universidad Autónoma de Campeche, Facultad de Contaduría y Administración. Av. Agustín Melgar S/N entre Calle 20 y Juan de la Barrera. Col. Buenavista. CP 24039

Universidad Juárez Autónoma de Tabasco, División Académica de Ciencias Económico-Administrativas. Av Universidad s/n, Magisterial, 86040 Villahermosa, Tab.

ID $1^{\text {st }}$ Author: Román Alberto, Quijano-García / ORC ID: 0000-0001-7316-1997, Researcher ID Thomson: G: 6014-2018, CVU CONACYT ID: 485854

ID $1^{\text {st }}$ Coauthor: Gilda María, Berttolini-Diaz / ORC ID: 0000-0001-5889-4429, Researcher ID Thomson: N-1435-2017, CVU CONACYT ID: 670973

ID $2^{\text {nd }}$ Coauthor: Luis Alfredo, Arguelles-Ma / ORC ID: 0000-0003-0315-4585, Researcher ID Thomson: S-5454-2018, CVU CONACYT ID: 300184

DOI: $10.35429 /$ EJRP.2019.9.5.1.11

Received August 15, 2019; Accepted November 30, 2019

\section{Abstract}

This study analyzes the dimensions of organizational culture and its possible influence in the quality of services offered by hotels in the city of Campeche that don't belong to big hotel chains. The research is descriptive with nonexperimental transversal design, considering the small hotels as population under study, which were enumerated according to the data of the Mexican Business Information System; the obtained results indicate that the organizational culture is based on the levels of trust developed among the collaborators, but the leader must encourage an open communication that strengthens its building, transmission and preservation, since the managers consider that the provided services don't have an adequate quality level, so new strategies must be desingned to improve the processes to innovate and remain in the market where they participate.

Organizational culture, Quality, Hotel sector

\begin{abstract}
Resumen
Este estudio analiza las dimensiones de la cultura empresarial y su posible influencia en la calidad de los servicios que ofrecen los hoteles que no pertenecen a cadenas hoteleras en la ciudad de Campeche. La investigación es descriptiva con diseño no experimental transversal, considerando como población a los hoteles pequeños, los cuales fueron censados dado su número según los datos del Sistema de Información Empresarial Mexicano; los resultados obtenidos señalan que la cultura organizacional se ha construido con base a los niveles de confianza fomentada entre los colaboradores, pero el líder debe fomentar una comunicación abierta que fortalezca la construcción, transmisión y preservación de la misma, ya que los gerentes consideran que los servicios otorgados no reúnen niveles adecuados de calidad, debiéndose diseñar nuevas estrategias para la mejora de los procesos para innovar y permanecer en el sector donde participan.
\end{abstract}

Cultura empresarial, Calidad, Sector hotelero

Citation: QUIJANO-GARCÍA, Román Alberto, BERTTOLINI-DIAZ, Gilda María and ARGUELLES-MA, Luis Alfredo. Organizational culture and quality under the management perception of the hotel sector. ECORFAN Journal-Republic of Peru. 2019. 5-9: 1-11.

\footnotetext{
* Correspondence to Author (email: rq6715@hotmail.com)

$\dagger$ Researcher contributing first author.
} 


\section{Introduction}

The last planning document of the Mexican government (Six-Year Development Plan), establishes that the tourism sector is a source of wealth for the country, and occupies the third place in the generation of foreign currency after the oil activity and the remittances of dollars that Mexicans who work abroad send, therefore, the promotion of tourism activity is essential for job creation and economic stability (National Development Plan, NDP 2013-2018).

According to the data of the National Statistical and Geographic Information System of Tourism (SNIEGT, 2019) at the end of 2018, the tourism sector generated 4,187,000 direct jobs, which represents $8.9 \%$ of the total economically active population employed, its contribution to National GDP is equal to $8.7 \%$ at the end of the third quarter of the same year.

For its part, the government of the state of Campeche, through the State Development Plan (PED 2015-2021), designed strategies and lines of action to strengthen tourism potential and thus generate jobs and economic growth along with the social welfare of the population through the organization of the sector, promoting a greater flow of direct investment and financing by raising the competitiveness of the activity in a sustainable way.

As main tourist assets, the State has the fortified city of Campeche, the only walled city in Mexico that has the UNESCO Cultural Heritage badge granted by UNESCO in 1999 as well as the Mixed Heritage (cultural and natural) ) granted to the ancient Mayan city and protected tropical forests of Calakmul since 2014. There are 16 archaeological areas open to the public where you can appreciate the Mayan culture, two site museums and 9 museum spaces (PED 20152021).

This work considers as part of the literature review studies developed on the quality of services in companies that participate in the tourism sector, as well as the way in which their organizational culture is developed and transmitted; In the methodology section the type and design of the study is established, as well as the participating variables, in addition to the characteristics of the population studied and the definitions of the instrument used to obtain information.
The statistical treatment of the data obtained is included in the results section, to finally be discussed and contrasted with the information of previous investigations that are part of the literature of the subject and that contribute to establish the final conclusions.

\section{Problem Statement}

Given the resurgence of the crisis in the oil sector that has consequences at international and national level, the strategies proposed in the economic planning documents seek to promote tourism investments of MSMEs, promoting the care and preservation of the country's cultural, historical and natural heritage (PND , 20132018). Based on the above, studies are required that contribute to the strengthening and development of the companies that participate in this sector, to turn them into organizations that offer competitive services at international level as required by globalization.

The hotel sector needs to be integrated by organizations that know their strengths and weaknesses at the level of infrastructure and processes under the leadership style of the decision maker, to position themselves in a market that demands quality in comprehensive services for national and foreign tourism.

\section{Objectives}

The organizational culture represents the set of processes and values created and transmitted by the administration to the collaborators of the companies (Velázquez 2005), therefore, this study intends the following objectives: a) Identify the elements that integrate the organizational culture in the MSMEs of the hotel sector of the city of Campeche, b) Identify the dimensions of quality in the operations of the participating organizations and c) Establish the perception of managers regarding culture and its impact on the quality of hotel services in the city

\section{Theoretical framework}

\section{Organizational culture in the tourism sector}

Wallingre (2005) considers that it is necessary to implement an innovative organizational culture in hotel SMEs, as this activity is a fundamental factor for the socio-economic development of countries. 
Synergy, commitment and creativity in collaborators contribute to the management of organizational culture by favoring teamwork, (Goncalvez, Goncalvez and Narloch, 2006); Therefore, every company has an implicit organizational system according to its level of structure. On the other hand Uzcátegui, Solano and Matute (2017), consider that the Quinn model provides the methodological framework to diagnose organizational culture and business performance.

Tarore (2016), analyzed the organizational culture and learning to establish its effects on commitment and empowerment and notes that organizational commitment has no effect on performance while learning and empowerment are factors that contribute to the results of Business.

The strategic planning of the companies is the reflection of the organizational culture and those with market orientation favor intensive work and develop defensive strategies, while those of ad hoc style compete through the differentiation of the products and services they offer. (Esparza and García, 2011).

Several studies indicate that culture and its values favor innovation by interacting with management to design new and better processes that facilitate adaptation to constant changes in the market through commitment, training and motivation of human resources, (Pérez 2003, Kyriakidou and Gore 2005 and Gálvez 2011).

Ortiz, Daza and Labarcés (2014), studied the development of strategies to favor the increase of productivity, identifying the organizational culture through physical working conditions, work environment and organizational behavior; its results indicate that the collaborators who claim to have good interpersonal relationships and communication; They feel support in the way in which conflicts are resolved, they are satisfied with the working conditions, equipment and security offered to them, these elements together allow maintaining acceptable levels of productivity to achieve the objectives.

\section{Quality in SME hotel services}

Monsalve and Hernández (2015), consider as several authors that the service offered in the hotels is fundamental for the sustainable development of tourist destinations and as part of their research they identified management variables that influence the quality of service among which They highlight the loyalty, promotion, innovation, promise of sale, equipment and training of human talent, conclude that a successful tourist destination requires citizen participation, business and government groups, in addition to education institutions, to prevent deterioration and resource depletion, integrating the local community into the project.

When studying a business case González and Vilalta (2007), they designed and implemented a guide for self-diagnosis of quality as a tool for their management that allowed them to specify ideas and align the efforts of the work developed to improve it.

Gutiérrez and Rubio (2009) considered the need for a change in the culture of tourism businesses and identified the human factor as a fundamental element in the management of service quality, the above when observing the increase in competition linked to the improvement of quality and its management systems, where the human factor is finally mentioned but not involved as a key piece in the development of services to achieve customer loyalty and satisfaction; The foregoing defines the client as the sole evaluator of the quality and subjectivity of their perception. Guerra and Cardozo (2010) considered that the management by competences is a tool that contributes to guarantee the quality of the service in the tourist inns of Tachida Venezuela, these researchers consider the human factor as essential in the sector, therefore, they identify the need to train and train staff in a planned way, measure their performance and thus together with other elements to evaluate the service. 
The recognition of the quality of hotel services influences the satisfaction obtained by the client, Fuentes, Hernández and Morini (2016) were able to establish that the average quality of services in five-star hotels is high and the client does not observe a difference significant; the differences are greater in threestar hotels, where managers often have little guidance on how to establish whether the experience of the service provided to the customer is satisfactory. Reyes, Guzmán and Morales (2015) elaborated a work that allowed them to know the expectations and perceptions of the tourist regarding lodging in Acapulco, Gro., Using the Servqual model, among their findings it highlights that the best evaluated variable was the human resource, for above expectations, but not in the case of facilities and equipment, which allowed them to point out the need to modernize the traditional areas of the tourist destination to recover the level of occupation and competitiveness.

Ibañez (2011), made a diagnosis of the quality and competitiveness of the tourism sector in Mexico considering that the globalization of the economy intensifies competition between destinations, pointing out the need to undertake efforts to maintain the privileged position that Mexico had, who has not yet It has consolidated the culture of quality and competitiveness which originates its tendency to lag in the ranking of the main tourist destinations in the world, for which it recommends implementing programs that certify the training of personnel, granting facilities for companies and workers to obtain certifications in quality, originate truthful and up-to-date information from government institutions, improving access to information; incentivize socially responsible companies to promote the use of alternative energy and revalue the human resources of all levels, which has an impact on the image that the company, the destination and the country offer the tourist.

\section{Research methodology}

Descriptive study because information is measured or collected on the analyzed variables, with a non-experimental cross-sectional design since data were collected at a single moment in their natural context, through questionnaires administered to the MSME managers of the hotel sector.
The method used for the collection of quantitative information is through fieldwork and the technique used is the survey (Hernández, Fernández and Baptista, 2016).

\section{Subjects in the study}

The population conformed with tourist MSMEs of the hotel sector, specifically those that do not belong to chains or franchises of the city of Campeche and whose culture was previously studied by Quijano, Arguelles, Medina and Fajardo (2017); The companies identified were 26, according to the Mexican Business System directory as of February 2, 2016. Of the 26 hotels identified, 23 agreed to participate.

\section{Instrument}

Questionnaire formulated by Mul, Mercado and Ojeda (2013) who designed it to study how knowledge is managed in companies in southeastern Mexico and includes reagents related to organizational culture, the integration of the instrument is described in Table 1.

\begin{tabular}{|c|c|c|c|}
\hline Dimension & $\begin{array}{c}\text { Operational } \\
\text { definition }\end{array}$ & Reagents & Proportion \\
\hline $\begin{array}{l}\text { Open } \\
\text { communication }\end{array}$ & $\begin{array}{l}\text { Process by } \\
\text { which } \\
\text { knowledge is } \\
\text { transferred } \\
\text { among the } \\
\text { members of } \\
\text { the entity. }\end{array}$ & $\begin{array}{r}53,55,58 \\
70,71,72\end{array}$ & $15.70 \%$ \\
\hline Trust & $\begin{array}{l}\text { It is the } \\
\text { willingness to } \\
\text { share } \\
\text { knowledge } \\
\text { fluidly. }\end{array}$ & $\begin{array}{r}46,47,48, \\
49,50,54\end{array}$ & $15.7 \%$ \\
\hline $\begin{array}{l}\text { Collaboration } \\
\text { and support }\end{array}$ & $\begin{array}{l}\text { It is the } \\
\text { management } \\
\text { intervention } \\
\text { to facilitate } \\
\text { and } \\
\text { encourage } \\
\text { knowledge to } \\
\text { permeate } \\
\text { throughout } \\
\text { the } \\
\text { organization. }\end{array}$ & $\begin{array}{r}51,52,64, \\
66,67,69\end{array}$ & $15.7 \%$ \\
\hline Clear structure & $\begin{array}{l}\text { They are the } \\
\text { processes or } \\
\text { mechanisms } \\
\text { that facilitate } \\
\text { the } \\
\text { acquisition } \\
\text { and } \\
\text { transmission } \\
\text { of } \\
\text { knowledge. }\end{array}$ & $\begin{array}{r}56,57,59, \\
60,61,62, \\
63,65,68\end{array}$ & $24.0 \%$ \\
\hline
\end{tabular}

Table 1 Elements of the organizational culture questionnaire applied to hotel managers

Source: own elaboration with data from Mul, Mercado and Ojeda (2013) 
The instrument has a section that collects socio-demographic information and the manager's administrative profile, as well as the company's positioning in the market. In the case of the quality variable, the questionnaire designed by Parasuraman, Zeithaml and Berry (1985) was used. This instrument is linked to the objectives of the investigation by contributing to the identification of the expectations and perception that hotel managers have regarding the services offered by participating companies, (Table 2).

\begin{tabular}{|c|c|c|c|}
\hline Dimension & $\begin{array}{c}\text { Operational } \\
\text { Definition }\end{array}$ & Reagents & Proportion \\
\hline Tangibility & $\begin{array}{l}\text { It is the } \\
\text { operational and } \\
\text { administrative } \\
\text { infrastructure } \\
\text { that serves as } \\
\text { the basis for the } \\
\text { services offered } \\
\text { by the } \\
\text { organization. }\end{array}$ & $1,2,3,4$ & $22.2 \%$ \\
\hline Reliability & $\begin{array}{l}\text { These are the } \\
\text { processes } \\
\text { developed by } \\
\text { the company's } \\
\text { personnel } \\
\text { through which } \\
\text { the services are } \\
\text { provided. }\end{array}$ & $\begin{array}{r}5,6,7,8 \text {, } \\
\text { r }\end{array}$ & $27.7 \%$ \\
\hline $\begin{array}{l}\text { Answer's } \\
\text { capacity }\end{array}$ & $\begin{array}{l}\text { Operations } \\
\text { carried out by } \\
\text { the } \\
\text { organization's } \\
\text { employees in a } \\
\text { timely manner. }\end{array}$ & $10,11,12$ & $16.7 \%$ \\
\hline Warranty & $\begin{array}{l}\text { Performing } \\
\text { processes by } \\
\text { staff with } \\
\text { attitude and } \\
\text { vocation of } \\
\text { customer } \\
\text { service. }\end{array}$ & $13,14,15$ & $16.7 \%$ \\
\hline Empathy & $\begin{array}{l}\text { They are the } \\
\text { processes } \\
\text { developed by } \\
\text { the } \\
\text { collaborators } \\
\text { with a sense of } \\
\text { identity towards } \\
\text { the client. }\end{array}$ & $16,17,18$ & $16.7 \%$ \\
\hline
\end{tabular}

Table 2 Definitions of the quality questionnaire administered to hotel managers

Source: own elaboration with data from Parasuraman, Zeithaml and Berry (1985)

Both instruments consider scores assigned on a Likert scale with values ranging from $1=$ Strongly disagree, $2=$ Disagree $3=$ Agree and $4=$ Strongly agree.

\section{Instrument Reliability}

The pilot test of both instruments was developed with $10 \%$ of the population to adapt them to the participating population; Cronbach's alpha was determined with a value of 0.800 for organizational culture and 0.902 for quality. When the test is replicated, the values in general for each variable and dimension are shown in Table 3.

\begin{tabular}{|l|l|r|r|}
\hline Variable & \multicolumn{1}{|c|}{ Dimension } & \multicolumn{1}{c}{$\begin{array}{c}\text { Number } \\
\text { of items }\end{array}$} & $\begin{array}{c}\text { Cronbach's } \\
\text { alpha }\end{array}$ \\
\hline Culture & & 27 & 0.961 \\
\hline & $\begin{array}{l}\text { Open } \\
\text { communication }\end{array}$ & 6 & 0.841 \\
\hline & Trust & 6 & 0.876 \\
\hline & $\begin{array}{l}\text { Collaboration } \\
\text { and support }\end{array}$ & 6 & 0.900 \\
\hline & Clear structure & 9 & 0.919 \\
\hline Quality & Tangibility & 18 & 0.937 \\
\hline & Reliability & 5 & 0.887 \\
\hline & Answer's & 3 & 0.874 \\
\hline & capacity & & 0.770 \\
\hline & Warranty & 3 & 0.720 \\
\hline & Empathy & 3 & 0.535 \\
\hline
\end{tabular}

Table 3 Reliability of the organizational culture and quality questionnaires administered to managers Source: own elaboration based on statistical information

The questionnaires were personally applied to hotel managers with a duration of twenty minutes each, and the data was processed through SPSS version 21 software.

\section{Results}

From the initial section of the instrument related to the sociodemographic aspects of the collaborators (established in previous studies on knowledge management Quijano, Arguelles and Fajardo, 2017), it was established that the age range with the highest frequency is between 41 and 50 years, having as business experience between 9 and 12 (30.4\%). From the administrative profile of the organizations it is observed that $69.6 \%$ of the companies have between 5 and 13 employees, $50 \%$ of the respondents consider having a good level of competitiveness indicating that their main competitive advantage is the price of the services they provide ( $42.4 \%$ ), followed by their quality $(27.3 \%)$ and in the same percentage the type of service. 
Regarding the commercial relations with the sectors to which they provide services, $47.8 \%$ consider that they are good with the government sector, with the private sector $78.3 \%$ and in the social sector $60.9 \% .73 .9 \%$ of the companies have as main objective the obtaining of profits, which is affected by the difficulties to hire qualified personnel $(24.6 \%)$ and the competition (13.8\%) and to face these challenges, a true internal and external communication It is the strategy that has worked best for $26.8 \%$ of respondents.

The organizational culture questionnaire includes three dimensions and the five quality one, through the calculation of the mean and standard deviation, the closest and most distant reagents of the values assigned in the instruments were identified, being able to observe the degree of dispersion of the responses, (Table 4).

\begin{tabular}{|c|c|c|c|c|c|}
\hline Dimension & $\mathbf{N}$ & 声 & 晋 & $\sum_{\Sigma}^{\bar{E}}$ & 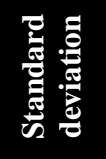 \\
\hline \multicolumn{6}{|c|}{ Organizational culture } \\
\hline $\begin{array}{l}\text { Open } \\
\text { communication }\end{array}$ & 23 & 1 & 4 & 2.81 & 4.003 \\
\hline Trust & 23 & 1 & 4 & 3.00 & 3.813 \\
\hline $\begin{array}{l}\text { Collaboration and } \\
\text { support }\end{array}$ & 23 & 1 & 4 & 2.86 & 4.238 \\
\hline Clear structure & 23 & 1 & 4 & 2.95 & 6.861 \\
\hline \multicolumn{6}{|l|}{ Quality } \\
\hline Tangibility & 23 & 2 & 4 & 2.94 & 2.0879 \\
\hline Reliability & 23 & 2 & 4 & 3.21 & 2.5568 \\
\hline Answer's capacity & 23 & 2 & 4 & 3.05 & 1.6693 \\
\hline Warranty & 23 & 2 & 4 & 3.31 & 1.2960 \\
\hline Empathy & 23 & 1 & 4 & 3.17 & 1.3440 \\
\hline
\end{tabular}

Table 4 Descriptive statistics of the leadership and quality variables

The table indicates the average of the values assigned by the respondents with respect to the variables studied, in no case the averages reach the highest value established, the above is corroborated with the dispersion in the responses. Source: Statistical information obtained from the survey previously determined by Quijano et al (2017).
In the case of the organizational culture variable, the highest average is 3 and corresponds to the dimension "Trust" and the lowest 2.81 and belongs to "Open communication", which indicates that in these companies the strategic decisions are not quickly transmitted to the staff of the organization and that the conflicts are not openly commented, although they have achieved a high level of "face-to-face" interaction with the employees and the ideas of the employees are heard, under a climate of trust and openness, Table 5.

\begin{tabular}{|c|c|c|c|c|}
\hline Reagent & 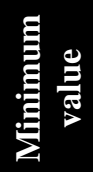 & 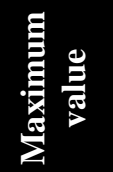 & $\sum_{\bar{E}}^{\bar{E}}$ & 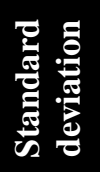 \\
\hline $\begin{array}{l}\text { 48. There is a high level of } \\
\text { face-to-face interaction } \\
\text { between workers in the } \\
\text { workplace. }\end{array}$ & 1 & 4 & \begin{tabular}{|l|l}
3.04 \\
\end{tabular} & 1.065 \\
\hline $\begin{array}{l}\text { 47. In the company there is } \\
\text { an atmosphere of trust and } \\
\text { openness. }\end{array}$ & 1 & 4 & 3.17 & 0.650 \\
\hline $\begin{array}{l}\text { 46. The company promotes } \\
\text { job security and the } \\
\text { existence of little } \\
\text { uncertainty. }\end{array}$ & 1 & 4 & 3.13 & 0.626 \\
\hline $\begin{array}{l}49 . \quad \text { Information flows } \\
\text { easily at all levels of the } \\
\text { organization. }\end{array}$ & 1 & 4 & 2.74 & 0.864 \\
\hline $\begin{array}{l}\text { 54. The company values } \\
\text { informal communication } \\
\text { networks. }\end{array}$ & 1 & 4 & 2.83 & 0.778 \\
\hline $\begin{array}{l}\text { 50. In the company the } \\
\text { ideas of the employees are } \\
\text { heard. }\end{array}$ & 1 & 4 & 3.09 & 0.793 \\
\hline
\end{tabular}

Table 5 Descriptive statistics regarding the trust dimension

Source: Statistical information obtained from the survey, previously determined by Quijano et al (2017)

In the case of the quality variable, none of the five dimensions obtained values close to 4, the highest corresponds to the "guarantee" dimension, and the lowest "tangibility", which indicates that the managers of the companies consider that the personnel inspire customer trust, but facilities and infrastructure must be improved. On the other hand, "reliability" is the dimension that obtained a greater dispersion in the responses, which indicates that in most organizations, personnel need to commit more to the service policies offered by companies in terms of time and characteristics, (Table 6). 


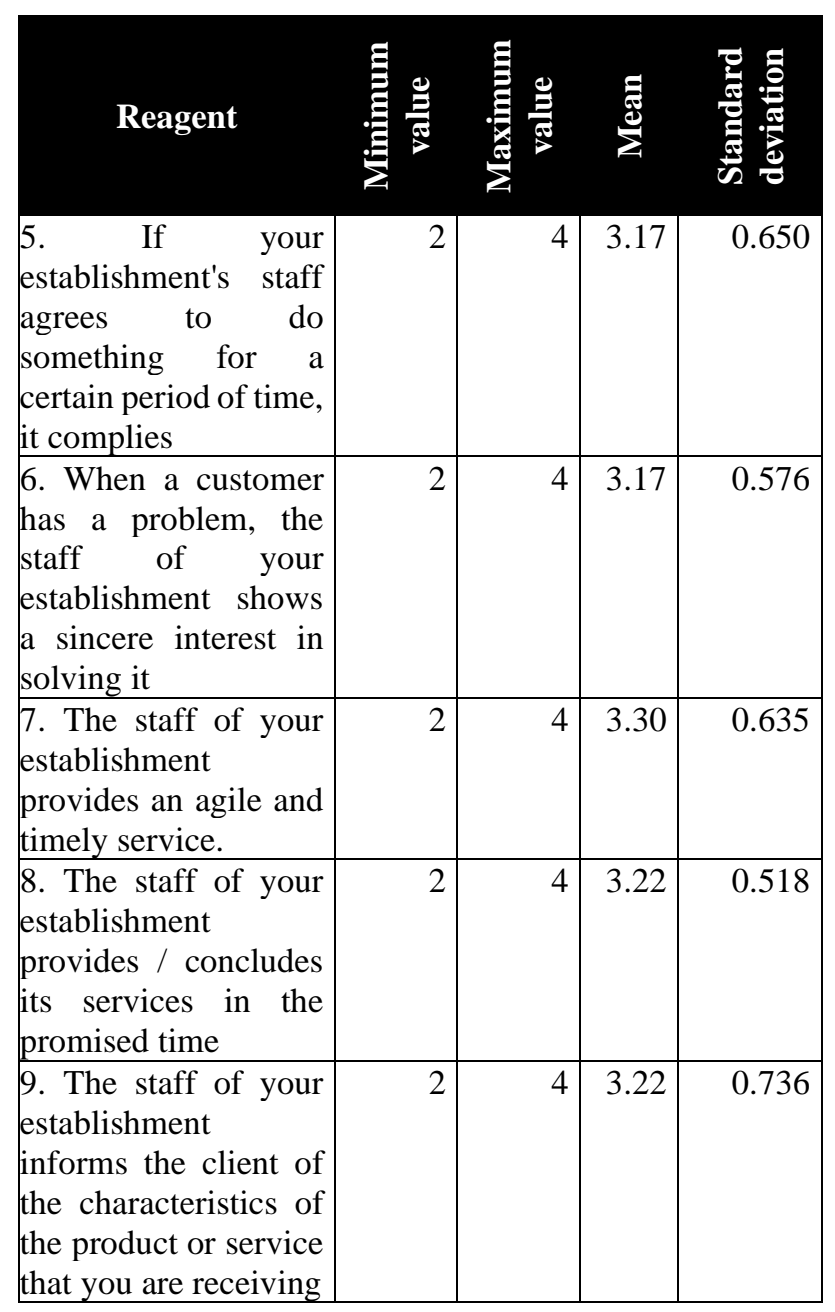

Table 6 Descriptive statistics regarding the reliability dimension of the quality variable

The smallest dispersion in the opinions of the respondents was obtained by the "guarantee" dimension, which indicates that in general the personnel of the participating companies transmit confidence to the clients, inspiring them security (Table 7).

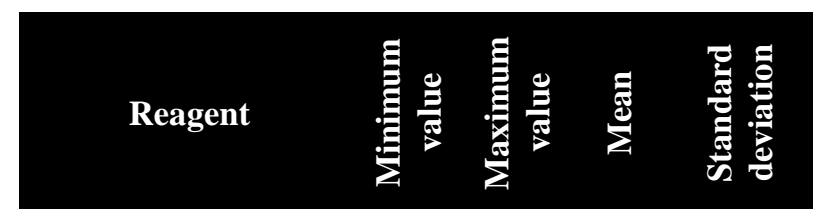

\begin{tabular}{|l|r|r|r|r|}
\hline $\begin{array}{l}\text { 13. The staff of your } \\
\text { establishment inspires / } \\
\text { transmits trust to } \\
\text { customers }\end{array}$ & 2 & 4 & 3.13 & 0.458 \\
\hline $\begin{array}{l}\text { 14. Customers of your } \\
\text { establishment feel safe } \\
\text { in their facilities }\end{array}$ & 2 & 4 & 3.30 & 0.635 \\
$\begin{array}{l}\text { 15. The staff of your } \\
\text { establishment is always } \\
\text { friendly with customers }\end{array}$ & 3 & 4 & 3.52 & 0.511 \\
\hline
\end{tabular}

Table 7 Descriptive statistics regarding the guarantee dimension of the quality variable
To assess whether sociodemographic and business factors affect the variables, the Student's T test was determined for independent tests (gender and marital status), and the ANOVA to determine the most relevant differences between variances of the values grouped into ranges; In both procedures, no statistical differences were identified for the organizational culture variable.

In the case of the quality variable when analyzing gender, significant differences were obtained in the "guarantee" dimension, which allows us to infer that this factor affects subjective aspects such as customer trust towards staff, according to the opinion expressed by the management; Similarly, the "tangibility" dimension reported differences in assessing the type of school where the last studies were conducted, whether public or private, as well as the seniority of the manager in the position and the number of employees of the organization, which may originate of the experience acquired when performing the duties of the position; In the case of the number of workers who collaborate in the company and the type of school, it is inferred that this element of the administrative profile affects the decision to participate in courses of non-governmental instances, organize formal training for employees, share project information and in the hiring of specialized personnel.

On the other hand, the "response capacity" dimension presented statistical differences with respect to the age factor, which represents an important aspect to evaluate, since according to management's opinion it can affect the moment of carrying out operations without errors or availability to solve customer questions from other collaborators.

With the values obtained from the instrument, indices were designed that facilitate interpreting the perception that the management body has regarding the influence of the organizational culture on the quality of the services offered; They were called the Organizational Culture Index (OCI) and Quality Index (IC) which were determined by expressing as a percentage the ratio of the division of the individual scores of each company between the maximum value that could be obtained according to the number of reagents each instrument 
A greater value of OCI and IC, means that the manager has a better perspective of the organizational culture and its impact on the quality of the services provided by the hotels, (Table 8).

\begin{tabular}{|c|c|c|c|c|c|c|}
\hline \multicolumn{4}{|c|}{$\begin{array}{l}\text { Organizational } \\
\text { Culture Index }\end{array}$} & \multicolumn{3}{|c|}{ Quality Index } \\
\hline 总 & 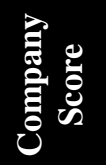 & 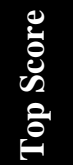 & $\begin{array}{l}\text { OCI } \\
(\%)\end{array}$ & 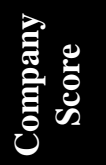 & $\begin{array}{l}\mathscr{D} \\
\tilde{8} \\
\tilde{E} \\
\tilde{\theta} \\
\tilde{E}\end{array}$ & $\begin{array}{l}\text { IC } \\
(\%)\end{array}$ \\
\hline 1 & 64 & 108 & 59.26 & 43 & 72 & 56.40 \\
\hline 2 & 60 & 108 & 55.56 & 64 & 72 & 55.81 \\
\hline 3 & 68 & 108 & 62.96 & 48 & 72 & 47.09 \\
\hline 4 & 95 & 108 & 87.96 & 66 & 72 & 81.98 \\
\hline 5 & 106 & 108 & 98.15 & 64 & 72 & 83.14 \\
\hline 6 & 95 & 108 & 87.96 & 67 & 72 & 86.63 \\
\hline 7 & 82 & 108 & 75.93 & 53 & 72 & 69.77 \\
\hline 8 & 108 & 108 & 100.00 & 69 & 72 & 94.19 \\
\hline 9 & 102 & 108 & 94.44 & 64 & 72 & 59.88 \\
\hline 10 & 81 & 108 & 75.00 & 54 & 72 & 67.44 \\
\hline 11 & 103 & 108 & 95.37 & 60 & 72 & 86.63 \\
\hline 12 & 64 & 108 & 59.26 & 62 & 72 & 56.40 \\
\hline 13 & 7 & 108 & 69.44 & 51 & 72 & 60.47 \\
\hline 14 & 77 & 108 & 71.30 & 57 & 72 & 69.77 \\
\hline 15 & 77 & 108 & 71.30 & 57 & 72 & 69.77 \\
\hline 16 & 80 & 108 & 74.07 & 53 & 72 & 57.56 \\
\hline 17 & 76 & 108 & 70.37 & 54 & 72 & 58.14 \\
\hline 18 & 80 & 108 & 74.07 & 54 & 72 & 58.14 \\
\hline 19 & 67 & 108 & 62.04 & 50 & 72 & 45.93 \\
\hline 20 & 67 & 108 & 62.04 & 48 & 72 & 45.93 \\
\hline 21 & 35 & 108 & 32.41 & 48 & 72 & 31.98 \\
\hline 22 & 73 & 108 & 67.59 & 54 & 72 & 43.02 \\
\hline 23 & 73 & 108 & 67.59 & 50 & 72 & 43.02 \\
\hline \multicolumn{7}{|c|}{$\begin{array}{l}\text { OCI = Organizational culture index = Maximum score } \\
\text { / Score x } 100 \text {. The result can be interpreted as the } \\
\text { manager's perception of the organizational culture } \\
\text { present in the organization. } \\
\text { QI = Quality index = Maximum score / score x } 100 \text {. The } \\
\text { result obtained for each company is the manager's } \\
\text { perception of the services offered and their quality. } \\
\text { Source: self made. }\end{array}$} \\
\hline
\end{tabular}

Table 8 Organizational Culture Index (OCI) and Quality Index (IC)

According to the results of Table 8 , the average of the OCI is $72.7 \%$, therefore, formal communication networks must be reinforced and the responsible behavior and willingness of employees to learn to strengthen teamwork should be valued; The average obtained from the CI of the population studied is 62.13, which gives an idea of the opinion that managers have regarding the quality of their services, and that contrary to what one might think they do not consider them to be adequate.
The results of Table 8 were compared to study the relationship between managers' perception regarding the impact of organizational culture on the quality of services provided by each organization and assess whether there is a correlation between the variables, through the analysis Linear regression determined the Pearson coefficient $(r=0.84103)$ and the coefficient of determination ( $\mathrm{r} 2=$ $70.7 \%$ ), which was obtained by squareing the previously obtained value of the Pearson coefficient. (Lind, Marchal and Wathen, 2012).

\section{Conclusions}

\section{Discussion of results}

When comparing the results of the investigations considered in the literature review with those obtained in this study, the importance of disseminating the strategic planning elements of the participating organizations and that the collaborators know their mission, vision, values and objectives can be pointed out. as an integral part of the organizational culture and achieve the differentiation of its services as proposed by Esparza and García (2011); Likewise, the structures of the processes and the reward schemes that foster commitment and values among the collaborators must be clearly defined in order to have a permanently motivated human resource, as proposed by Pérez (2003) and Gálvez (2011). Among the results analyzed, trust stands out as the dimension best perceived by collaborators in the organizational culture, which indicates that in companies there is an open environment with job security, which minimizes the existence of uncertainty among staff, whose Ideas are heard favoring teamwork and coincide with what was studied by Goncalvez et. to (2006). It is observed that the means obtained as a whole for the quality dimensions will not be considered high since their average value ranges from three, the dimension with the lowest value being tangible, which indicates that infrastructure investment is not sufficient for standards that national and foreign guests demand according to the opinion of the managers of the organizations participating in the study, which is in contrast to what was suggested by Ibañez (2011), who points out that the image of tourism companies as a whole raises their level of occupation and competitiveness, therefore, it is desirable to assess whether the physical investment made to date is adequate according to service standards. 
On the contrary, the dimension called guarantee reached the average with the highest average, which indicates that employees are friendly to customers and generates a climate of trust and security, which confirms that the human factor is a fundamental element in the Quality management, and should be involved in the service delivery processes. The above is necessary to achieve customer loyalty and satisfaction, (Gutiérrez and Rubio, 2009).

Reliability is the dimension with the greatest dispersion in the responses expressed by managers, which indicates that the opinions do not coincide in the level of commitment of the other collaborators to solve the possible problems that guests have, it is desirable to encourage the provision of services based in values, norms and practices tending to satisfy the expectations of the client, (Reyes et. al, 2015). On the other hand, there is a coincidence in the managerial opinion regarding the kindness with which employees treat customers, which can be reinforced through training schemes and measuring their performance based on competencies and thus have a better profile design (Guerra and Cardozo, 2010).

\section{Conclusions}

Considering the objectives of the study, it is possible to point out that the participating companies should strengthen open communication as an element of the organizational culture, so that employees can move more easily to senior managers and that operational and administrative decisions are transmitted in a timely manner, and The organizational structure is clearly identified by all the members of the company, the above is reinforced with the average value not exceeding $75 \%$ determined through the organizational culture index. There are no documented mechanisms among the population for the development and dissemination of the business culture, which may originate from the need to design clear structures from jobs and command lines, to the recognition of tasks according to the assigned position.
The second objective of the research establishes the identification of the quality dimensions which are present however, this is not adequate from the point of view of the managers of the participating companies, who assign an average value of $62.13 \%$ according to the Exprofeso designed index, unexpected situation, since the managers to be employed are also responsible for the operation of the hotels. It requires an analysis of the current processes and propose quality management strategies that meet customer expectations which would be reflected in an increase in the quality index.

Finally, it was established that there is a relationship between the variables studied and it can be inferred that the organizational culture affects the quality of the services offered from the perspective of the managers. This research has as a limitation the number of companies and the personnel surveyed, developing similar studies in other regions of the country can help establish internal and external factors that affect the level of quality of services offered by companies in the hotel sector and that It is reflected in the levels of occupation and competitiveness within the market.

\section{References}

Esparza, J. y García, D. (2011). La cultura de las empresas familiares turísticas mexicanas y su influencia en la gestión estratégica. Cuadernos de Administración. 24, 42 enero-junio pp. 295311

Foronda, C. y García, A. (2009). La apuesta por la calidad como elemento diferenciador en los destinos turísticos: planes renovados. Cuadernos de Turismo. 23 pp. 89-110.

Fuentes, M., Hernández E. y Morini, S. (2016). $\mathrm{Q}$ de calidad y satisfacción del turista en el sector hotelero español. Cuadernos de Turismo. $37 \mathrm{pp}$. 203-226.

Gálvez, E. (2011). Cultura intraemprendedora e innovación: un estudio empírico en las mipymes turísticas colombianas. Cuadernos de Administración. 27, 46 pp. 103-114

Guerra, K. y Cardozo, N. (2010). La gestión por competencias. una herramienta para garantizar la calidad del servicio. caso de estudio posadas turísticas del estado Táchira. Provincia. 24 pp. 31-51. 
Gobierno del Estado de Campeche (2016). Plan Estatal de Desarrollo 2015-2021. Recuperado el 10 de marzo de 2016 en www.campeche.gob.mx

Gobierno Federal de los Estados Unidos Mexicanos, Presidencia de la República. (2016). Plan Nacional de Desarrollo 2013-2018. México. Recuperado de: www.presidencia.gob.mx

Goncalves, J., Goncalves, M., y Narloch C. (2006). La importancia de la cultura organizacional en la gestión de empresas turísticas: el caso de blue tree hotels. En http://www.esade.edu/cedit2006/pdfs2006/pape rsla_importancia_de_la_cultura_organizacional _en_la_gestión_de_empresas_turísticas.pdf

González, M. A., y Vilalta, J. A. (2007). La autoevaluación como herramienta para gestionar la calidad en pequeñas y medianas empresas con un destino turístico: una experiencia cubana. Revista Ingenieria Industrial, 28 (2), 38-41.

Gutiérrez, S. y Rubio, M. (2009). El factor humano en los sistemas de gestión de calidad del servicio: un cambio de cultura en las empresas turísticas. Cuadernos de Turismo. 23 pp. 129147.

Hernández, R., Fernández, C. y Baptista, P. (2016). Metodología de la investigación. Mc Graw Hill, México

Ibáñez, R. (2011). Diagnóstico de la calidad y competitividad del sector turístico en México. Cuadernos de turismo. 28 pp. 121-143.

Kyriakidou, O., Gore, J. (2005). Benchmarking organizational culture in hospitality, tourism and leisure SMEs. Benchmarking: An International Journal. 12 (3), pp. 192-206.

Lind D., Marchal W. y Wathen S. (2012). Estadística aplicada a los negocios y la economía. México: Mc. Graw Hill.

Monsalve, C., y Hernández, S. (2015). Gestión de la calidad del servicio en la hotelería como elemento clave en el desarrollo de destinos turísticos sostenibles: caso Bucaramanga. Revista Escuela De Administración De Negocios, (78), 160-173.
Mul, J., Mercado, L. y Ojeda, R. (2013). Propuesta de un instrumento para conocer las actividades de gestión del conocimiento y los factores organizativos que la influyen. Memorias en extenso del XVIII Congreso Internacional de Contaduría Administración e Informática, UNAM, México.

Ortiz, J., Daza, A. y Labarcés, C. (2014). La cultura organizacional de los operadores turísticos de Santa Marta 2013-2013. Clío América. Vol. 8.15 pp. 22-35

Parasuraman, A.; Zeithaml, V. y Berry, L. (1985). Servqual: a multiple ítem scale for measuring consumer perceptions of service quality. Journal of Retailing. 6.1. pp. 12-40.

Pérez, R. (2003). Propuesta de un modelo de gestión humana y cultura organizacional para pymes innovadoras. Revista Escuela de Administración de Negocios. 47 enero-abril pp. 46-65.

Quijano R., Arguelles L. Fajardo M. (2017). Cultura organizacional en mipymes turísticas de Campeche, México. Revista Internacional Administración \& Finanzas 10, 4 pp. 91-101.

Reyes, D., Guzmán, D. y Morales A. (2015). Diagnóstico de la calidad de los servicios de hospedaje en Acapulco, Guerrero. Revista Mexicana de Ciencias Agrícolas. 01 pp. 391393.

Secretaría de Economía (2016). Sistema de Información Empresarial Mexicano. Recuperado de www.siem.gob.mx

Secretaría de Turismo (2019). Sistema Nacional de Información Estadística y Geográfica de Turismo. Recuperado de www.datatur.sectur.gob.mx/SitePages/Resultad osITET.aspx

Tarore, J. (2016). The effects of organizational culture, learning organization, empowerment, and organizational commitment on the performance of SMEs (A case study of SMEs in the Regency of South Minahasa). IOSR Journal of Business and Management. Vol 8. Ver. II pp. 59-64. 
Uzcátegui, C., Solano, J. y Matute, G. (2017). Cultura organizacional y rendimiento empresarial de la pyme turística de la provincia de el oro. Memorias en extenso del XI Congreso Virtual Internacional Turismo y Desarrollo.

Velázquez, G. (2005). Liderazgo empático, un modelo de liderazgo para las organizaciones mexicanas. Revista del Centro de Investigación. pp. $81-100$

Wallingre, N. (2005). La necesidad de implementar una cultura organizacional innovadora en las Pymes hoteleras de Argentina. Revista Tiempo de Gestión, (1), 83-93 